\title{
Lean Mining, Productivity and Occupational Health and Safety: An Expert-Elicitation Study
}

\author{
Ali Nemati1 ${ }^{1}$ Sylvie Nadeau ${ }^{1 *}$, Barthélémy Ateme-Nguema ${ }^{2}$ \\ ${ }^{1}$ Mechanical Engineering Department, École de technologie supérieure, Montreal, Quebec, Canada \\ ${ }^{2}$ Management Sciences Department, Université du Québec en Abitibi-Témiscamingue, Quebec, Canada \\ Email: ^sylvie.nadeau@etsmtl.ca
}

How to cite this paper: Nemati, A., Nadeau, S. and Ateme-Nguema, B. (2019) Lean Mining, Productivity and Occupational Health and Safety: An Expert-Elicitation Study. American Journal of Industrial and Business Management, 9, 2034-2049. https://doi.org/10.4236/ajibm.2019.911134

Received: October 18, 2019

Accepted: November 25, 2019

Published: November 28, 2019

Copyright $\odot 2019$ by author(s) and Scientific Research Publishing Inc. This work is licensed under the Creative Commons Attribution International License (CC BY 4.0).

http://creativecommons.org/licenses/by/4.0/

\begin{abstract}
The implementation of lean tools in the Canadian mining industry is still in its beginnings. To the best of our knowledge, published information and articles on this subject are scarce. Consequently, the impacts of using lean tools on productivity and workers' health and safety in this field are still unclear and need more investigations to better integrate the technical aspects of lean with Occupational Health and Safety (OHS). Therefore, this study aims to provide insights about lean mining in Canada. The objective of this paper is to propose a preliminary road-map for lean implementation considering OHS concerns in Canadian underground gold-mining. To meet this objective, a set of lean tools (i.e. VSM, 5S, Kaïzen, TPM, SMED and LIC) as independent variable, and OHS indicators (i.e. "struck by an object" and "body reaction" risks) and an economic indicator (i.e. daily advance rate) as dependent variable were selected. An expert-elicitation study was conducted recruiting 7 experts from academia and practitioners active in the mining sector. Results show that the majority of experts agreed on a possible positive impact on a mine's daily advance rate after implementing $5 \mathrm{~S}$ and TPM, and a reduction of the risk rate of "struck by object" among workers by implementing Kaïzen.
\end{abstract}

\section{Keywords}

Lean Mining, Lean Tools, Occupational Health and Safety, Expert Elicitation, Preliminary Road-Map, Underground Gold Mine

\section{Introduction}

Lean manufacturing is originating from Toyota Motor Company. It was initially known as Toyota Production System (TPS) (Ohno, 1988) [1] and it started when 
Toyota discovered shortcomings in the Ford system especially with regards to employees participation. The Toyota management team then improved the TPS and introduced the lean manufacturing system to the world, a production system that helped them improve their productivity and increase their profits through systematic process waste removal (Shingo et al., 1989; Womack et al., 1990) [2] [3]. In the past three decades, many companies from different sectors have tried to implement lean management into their production platforms after witnessing the major success of lean at Toyota (Flynn et al., 2015; Bhamu et al., 2014) [4] [5]. To this effect, companies around the world and from various industrial sectors started using different tools to implement lean and eliminate or reduce seven stages of waste in their daily activities (Sternberg et al., 2012) [6]. Bhamu et al. (2014) [5] and Hodge et al. (2011) [7] summarize that tools such as five S (5S), Value Stream Mapping (VSM), Kaïzen, Single-Minute Exchange of Die (SMED) and Total Productive Maintenance (TPM) were mostly used and cited in the literature to implement lean in the manufacturing sector.

\section{Literature Review: Lean Mining}

There are plenty of publications on the results of lean tools in the manufacturing sector (Flynn et al., 2015) [4]. However, for the mining industry, there is little information and very few studies about lean implementation (Lööw, 2018; Hasle, 2014) [8] [9]. Sanchez et al. (2004) [10] mention that it might be possible to implement the principles of lean equally in every industry. On the other hand, Hattingh et al., (2010) [11] points out the different nature of the mining environment compared to the manufacturing sector and questions the possibility of successfully integrating lean tools in mining with the same approach as has been used in the manufacturing sector. In addition, Khaba et al. (2018) [12] point out that the level of lean awareness amongst miners could vary from one mine to another. Factors such as variability and uncertainty are known barriers in mining that can hinder the implementation of lean in this sector (Nadeau et al., 2015; Flynn et al., 2015) [13] [4]. Available literature addresses mainly the improvements in productivity once lean tools have been used (Castillo et al., 2014; Ade et al., 2012; Dunstan et al., 2006) [14] [15] [16]. Little or no information exists in the literature about the impacts of using lean tools on miner OHS conditions (Nadeau et al., 2015; Ade et al., 2012) [13] [15]. Table 1 summarizes the available studies that examine the use of lean tools in the mining sector. These studies can be categorized as follows based on the implemented lean tools:

- Lean Information Center (LIC): In conjunction with 5S, using LIC resulted in early stage performance improvement in an aluminum mine, cycle time reduction in a bauxite mine and cycle time enhancement in an underground copper mine (Dunstan et al., 2006) [16].

- 5S: Process time reduction in a coal mine (Liu, 2013) [17] and incident rate reduction in an aluminum mine (Dunstan et al., 2006) [16].

- VSM: Productivity improvement in a fluorspar mine, enhancement of process 
value-added and possible improvement in the miners' overall health in an amethyst mine (Flamarion Klippel et al., 2008) [18] and production rate increase in a coal mine (Ade, 2012) [15] and possible cycle time reduction in a diamond mine (Maunzagona et al., 2017) [19].

- Kaïzen: In conjunction with other tools such as VSM and 5S, using Kaïzen resulted in project performance and productivity enhancement in a copper mine (Castillo et al., 2014) [14] and possible improvements in the miners' health and safety conditions (Vaněk et al., 2015) [20].

- TPM: Repair time reduction in a copper mine (Chlebus et al., 2015) [21].

It is important to mention that there are certain differences in the legislative, environmental and geological conditions in each country specified in Table 1. Therefore, comparing these results may be difficult without considering these differences. Moreover, there are some drawbacks and limitations in the implementation of lean mining (Hines et al., 2018) [22]. There are different definitions of lean in the literature (Stone, 2012) [23]. Bhamu et al. (2014) [5] found over 33 different definitions of lean manufacturing while reviewing a wide range of literature. Among these definitions, one of the most cited in the literature is presented by Shah \& Ward (2007) [24]. Consequently, this paper has chosen it as its definition of lean: "An integrated socio-technical system whose main objective is to eliminate waste by concurrently reducing or minimizing supplier, customer, and internal variability" (Shah \& Ward, 2007: p. 791) [24]. Stahl et al., (2015) [25] argued that some companies are ignoring the actual concept of lean in a social sense and are using lean tools only for waste removal purposes and

Table 1. Available case studies on the topic of implementing lean tools in the mining sector.

\begin{tabular}{|c|c|c|c|c|c|}
\hline Country & Type of mine & Tool(s) & Effect(s) on economic aspect & Effect(s) on OHS aspect & Author \\
\hline Australia & Aluminum & LIC, 5S, TPM & $\begin{array}{l}\text { Performance improvement (in early stage } \\
\text { of lean implementation) }\end{array}$ & $\begin{array}{l}57 \% \text { decrease in the rate of incidents } \\
\text { among miners }\end{array}$ & {$[16]$} \\
\hline Australia & Bauxite & LIC \& 5S & Cycle time reduction & - & {$[16]$} \\
\hline Australia & $\begin{array}{l}\text { Underground } \\
\text { copper mine }\end{array}$ & LIC & $56 \%$ enhancement in the cycle time & - & {$[16]$} \\
\hline Brazil & Fluorspar & VSM & $43.6 \%$ raise in productivity & - & {$[18]$} \\
\hline Brazil & Amethyst & VSM & $\begin{array}{l}16.6 \% \text { improvement in the process } \\
\text { added-value time }\end{array}$ & $\begin{array}{l}\text { Possible enhancement in the miners' } \\
\text { health due to reduction of dust }\end{array}$ & {$[18]$} \\
\hline Chile & Copper & VSM, 5S, Kaizen & $\begin{array}{l}\text { Enhancement in project performance and } \\
\text { productivity }\end{array}$ & - & {$[14]$} \\
\hline Czech Republic & Coal & Kaizen & - & $\begin{array}{l}\text { Possible enhancement in the miners' } \\
\text { safety and health conditions }\end{array}$ & {$[20]$} \\
\hline India & Coal & VSM & $16.8 \%$ increase in production rate & $\begin{array}{l}\text { Possible reduction in the required } \\
\text { effort to move materials by miner after } \\
\text { installation of man-rider system }\end{array}$ & [15] \\
\hline Poland & Copper & $5 \mathrm{~S}, \mathrm{TPM}$ & Decrease in average repair time & - & {$[21]$} \\
\hline South Africa & Diamond & VSM & Cycle time reduction & - & [19] \\
\hline
\end{tabular}


improving their productivity. This approach can lead to limited and unsustainable results (Mazzocato et al., 2010; Repenning et al., 2001) [26] [27].

Moreover, improper implementation of lean, lack of experience in using lean tools, and lack of commitment from management can lead to negative outcomes while using lean tools (Ferreira et al., 2015; Dal Forno et al., 2014) [28] [29]. The employees' overall safety and health can be negatively affected by improper implementation of lean (Adler, 1999) [30]. Increasing the accident and injury rate in the workplace (De Treville et al., 2006) [31], deteriorating the level of health and increasing the stress level of employees (Brenner et al., 2004) [32], and adding onto the workload and intensity of the employees' job (Brännmark et al., 2012; Westgaard et al., 2011) [33] [34] have all reported negative results of improper usage of lean tools. On the other hand, lean can have positive impacts on OHS by involving workers on the job, enhancing the workers' training, and proposing improved tasks for them (Nadeau et al., 2015) [13]. However, to the best of our knowledge, the available relevant results about these possible effects in mining are still insufficient, which makes it difficult to compare one company to another (Dunstan et al., 2006; Flamarion Klippel et al., 2008; Ade et al., 2012; Vaněk et al., 2015) [15] [16] [18] [20]. So far, to the best of our knowledge and based on the limited published literature in mining, the technical aspects of lean have not yet been integrated with the OHS aspects. To fill this gap, the objective of this paper is to develop a preliminary road-map to help integrate lean tools into mining industries considering their impacts on the overall health and safety of miners.

\section{Methodology}

\subsection{Research Method: Identifying Variables}

As previously mentioned, information about the implementation of lean tools in mining regarding OHS issues is scarce in the literature (Nadeau et al., 2015) [13]. Therefore, to gain in-depth knowledge about this subject for this paper, a qualitative research approach was followed (Creswell, 2013; Fortin, 2010) [35] [36]. An expert elicitation study using semi-directed interviews was undertaken to discover any possible links between the integration of lean tools and the economical and OHS aspects of the mining sector (O'Hagan et al., 2006) [37]. The focus of the study is on an underground gold mine, at the extraction level and in the early stages of lean implementation in Canada. Therefore, Canadian experts who have previous work experience in the same field were considered as potential participants for interviews and data collection.

The first step in designing the expert elicitation method is to identify the variables involved. A set of lean tools that have been frequently used in the mining field were categorized as the independent variable (Chlebus et al., 2015; Nadeau et al., 2015; Castillo et al., 2014; Liu, 2013; Ade, 2012; Dunstan et al., 2006) [13]-[17] [21]. VSM, 5S, Kaizen, TPM and LIC are, in the literature, a pre-selected set of tools to be studied as an independent variable. Moreover, based on a pro- 
posal by Nemati et al. (2019) [38] as to the possibility of using SMED in an underground mining environment, this tool was added to the list of lean tools as an independent variable as well. To investigate the relationships between these tools and economic and OHS indicators in the mining environment, dependent variables needed to be defined as well. According to reports published by the Commission des Normes, de l'Équité, de la Santé et de la Sécurité du Travail (CNESST) and the Ministère de l'Énergie et des Ressources Naturelles (MERN), "struck by an object" and "body reaction" were two common OHS issues in underground gold mines in Québec (MERN, 2012; CNESST, 2011) [39] [40]. Therefore, these two indicators were selected as OHS-dependent variables. As for an economic indicator, increasing the rate of production is an important factor to consider in the mining field (Pareja, 2000) [41]. Taking into account the geological and environmental conditions in Canadian underground gold mines, productivity is tied with the daily advance rate for extracting ore (Pareja, 2000) [41]. Consequently, the advance rate per day was chosen as the economic dependent variable.

\subsection{Data Gathering and Analysis Method}

Holding a semi-directed interview with Canadian experts was deemed useful to record the expectations and perceived difficulties, challenges and successes in implementing lean tools from the experts' point of view. In a first step, the authors of this paper met with the Ethics Committee of École de technologie supérieure (ÉTS) and received their approval in September 2018. This compliance was followed by the approval of the Ethics Committee of Universite du Québec en Abitibi-Témiscamingue (UQAT). Subsequently, a total of 7 Canadian experts (a representative sample size Lehto \& Buck, 2008; Nielsen, 1993) [42] [43] were interviewed for this project. These experts were chosen amongst active academia and practitioners in the mining sector. Obtained data from the interviews were converted to text and then categorized using an Excel spreadsheet. By using this software, the important keywords within the text (i.e. productivity, productive, performance, safety, injury, health, OHS, prevention, positive, impact, link, more studies, increase, decrease, improve, improvement, avoid, effective, efficient, reduction, reduce, lean tools, profitable, cost) were categorized and sorted and their patterns were compared with each other to find meaningful behaviours (Berg, 2001) [44]. The output results were interpreted in the last step, that is, the identified patterns were studied and the results were compared with the literature to draw a conclusion. Figure 1 shows the different steps of the methodology of this research.

\section{Results}

As mentioned above, a semi-directed questionnaire was distributed to the experts. The experts' average age was $55( \pm 13)$. They had an average of $20( \pm 15)$ years of experience in the mining sector. $43 \%$ of them are active academia and 


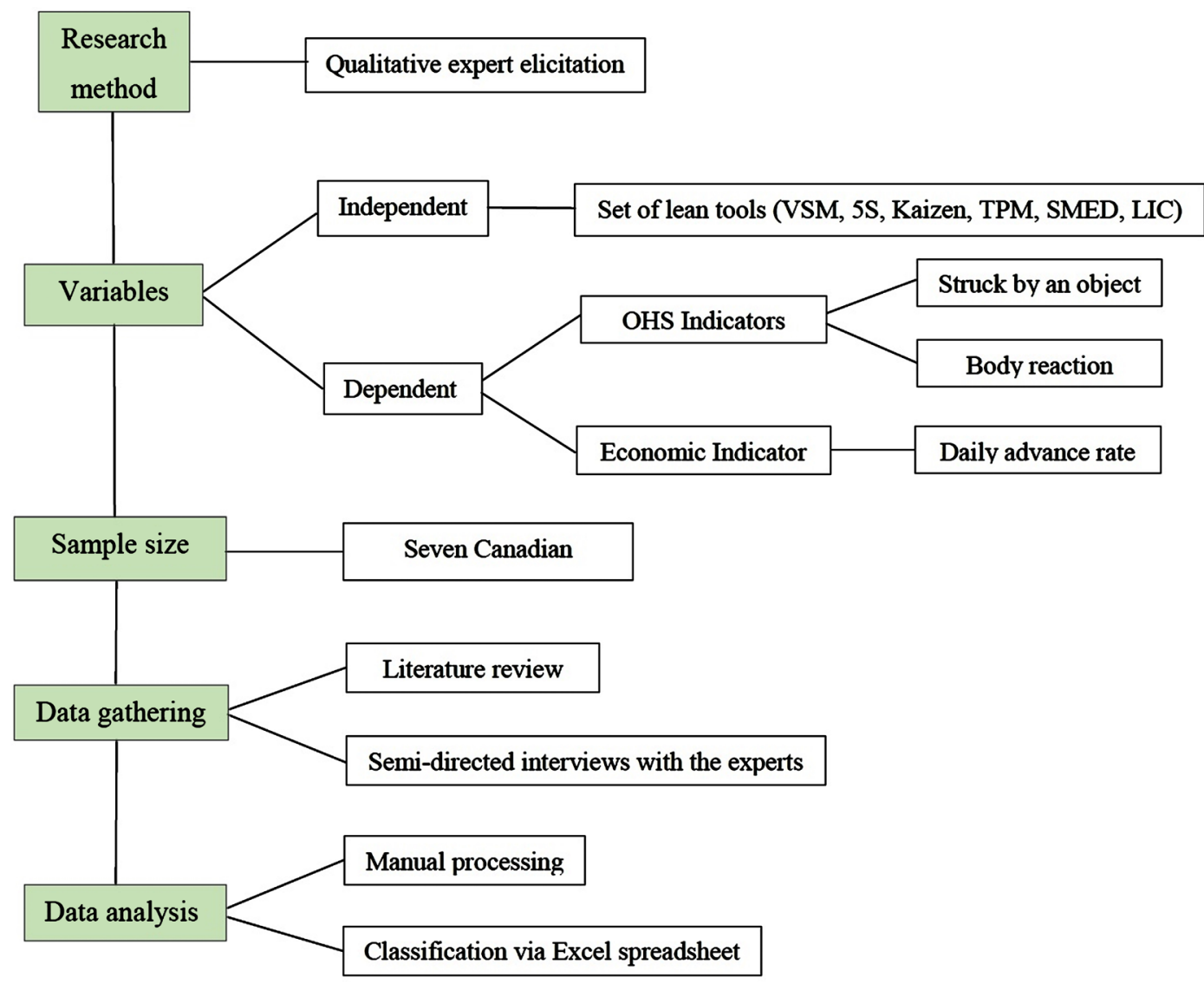

Figure 1. Methodology diagram of this research.

the other $57 \%$ are practitioners working in the mining industry. In the semi-directed questionnaire, the experts were all asked to express their opinion on the current level of lean implementation in Canadian underground gold mines. The majority agreed that this level is low. According to them, lean mining is hardly spoken of among workers in Canadian mines. Moreover, according to the experts in our sample, the use of lean by management teams in the mining industry is limited to improving productivity. A good $72 \%$ of the experts commented that implementing lean mining will increase the efficiency, improve the productivity and eliminate wastes within the underground mining environment. According to $88 \%$ of them, resistance to change among workers, managers and stakeholders could be the main existing barrier to the successful implementation of lean. Experts were asked to define lean from their own perspectives. Most of them $(72 \%)$ described lean as a management approach for reducing costs, minimizing loss of time and optimizing production. Regarding lean-related training, $88 \%$ of the experts stated that they did not have any prior formal training. Furthermore, the majority did not know precisely or were not sure what types of lean tools are being used for the implementation of lean in mining. The experts were also asked about their opinions regarding possible connections between the set of lean tools and each OHS and economic indicator. A summary of these results can be seen in Table 2 . 
Table 2. Available Results summary of experts' opinions regarding the relationship between lean tools and OHS and economic indicators.

\begin{tabular}{|c|c|c|c|c|}
\hline \multirow{2}{*}{\multicolumn{2}{|c|}{ Independent variables }} & \multicolumn{2}{|c|}{ OHS Indicators } & \multirow{2}{*}{$\begin{array}{l}\text { Economic indicator } \\
\text { Daily advance rate }\end{array}$} \\
\hline & & Struck by an object & Body reaction & \\
\hline \multirow{5}{*}{ A set of lean tools } & VSM & $\begin{array}{l}\text { - } 57 \% \text { did not know if there was a link. } \\
\text { - It depends on the mine. }\end{array}$ & $\begin{array}{l}\text { - } 71 \% \text { did not know if there } \\
\text { was a link. }\end{array}$ & $\begin{array}{l}\text { - } 71 \% \text { did not know if there was a link. } \\
\text { - It can increase the paper work. }\end{array}$ \\
\hline & $5 S$ & $\begin{array}{l}\text { - } 57 \% \text { did not know if there was a link. } \\
\text { - It might be difficult to sort the } \\
\text { mining supplies. }\end{array}$ & $\begin{array}{l}\text { - } 43 \% \text { did not think there was } \\
\text { a link. }\end{array}$ & $\begin{array}{l}\text { - } 43 \% \text { believed that there is a link. } \\
\text { - It can increase productivity. }\end{array}$ \\
\hline & Kaizen & $\begin{array}{l}\text { - } 57 \% \text { agreed that there is a link. } \\
\text { - Elimination of bottleneck. } \\
\text { - Better understanding of tasks and } \\
\text { responsibilities. }\end{array}$ & $\begin{array}{l}\text { - } 43 \% \text { did not know if there } \\
\text { was a link. }\end{array}$ & $\begin{array}{l}\text { - } 43 \% \text { did not know if there was a link. } \\
\text { - } 43 \% \text { believed that there could be a } \\
\text { positive link. }\end{array}$ \\
\hline & SMED & - $57 \%$ did not know if there was a link. & $\begin{array}{l}\text { - } 86 \% \text { did not know if there } \\
\text { was a link. }\end{array}$ & - $57 \%$ did not know if there was a link. \\
\hline & LIC & - $57 \%$ did not know if there is a link. & $\begin{array}{l}\text { - } 57 \% \text { did not know if there is } \\
\text { a link. }\end{array}$ & - $43 \%$ did not know if there is a link. \\
\hline
\end{tabular}

\subsection{VSM}

For VSM, the majority of the experts did not think or were not sure whether there is a link between this lean tool and "struck by object" risks (57\%), "body reaction" risks (71\%) and "daily advance rate" (71\%). This could indicate that more studies are required to assess the outcomes of using VSM on the OHS and productivity indicators for an underground mining environment.

\subsection{Five $S$}

As for $5 \mathrm{~S}, 57 \%$ of the experts did not know if there is a connection between $5 \mathrm{~S}$ and "struck by object" risks and $43 \%$ did not think there was a possible link between $5 \mathrm{~S}$ and "body reaction" risks. On the other hand, the majority of the experts (43\%) believe there is a connection between the "daily advance rate" and 5S. Improving productivity is a positive effect of using $5 \mathrm{~S}$ in the mining industry from these experts' point of view. This means that, in the experts' perspective, implementing $5 \mathrm{~S}$ elements in the workplace should improve the daily advance rate.

\subsection{Kaizen}

More than half of the experts (57\%) agreed that a link exists between Kaizen and "struck by object" risks. Elimination of bottlenecks, better understanding of the tasks and responsibilities are a few of the reasons given by the experts regarding the positive effects of implementing Kaizen. This indicates that by having an optimal process and implementing continuous improvement practices in the 
workplace, the "struck by object" risks should decrease. For the other OHS indicator, the majority of the experts (43\%) did not know if there is any link between Kaizen and "body reaction" risks. Eventually, less than half of the experts (43\%) responded that they do not know whether there is a link between this lean tool and the "daily advance rate" for Canadian underground gold mines. That being said, the same number of experts (43\%) commented that there might be a positive link. These experts agreed that Kaizen could improve productivity and enhance efficiency through continuous improvement practices.

\subsection{TPM}

For this tool, the majority of the experts did not know if a link could be made between TPM and "struck by object" risks (43\%). The results are divided in two groups as for "body reaction" risks. A first group of $43 \%$ did not know about a link while the other $43 \%$ mentioned that there is no link to be made between these two variables. The majority of the experts (57\%) mentioned that there could be a link between TPM and productivity. According to these experts, increasing the "daily advance rate" and obtaining an uninterrupted production pace can be achieved by properly implementing TPM. This indicates that performing a regular maintenance according to the TPM guideline should improve the productivity of the underground mine.

\subsection{SMED}

Similar to VSM, the majority of the experts did not know if a connection could be made between SMED and "struck by object" risks (57\%), "body reaction" risks (86\%) and "daily advance rate" (57\%). This could mean that the obtained results are inconclusive and that more studies are needed to investigate the outcome of using SMED on OHS and productivity indicators in the mining environment more thoroughly.

\subsection{LIC}

Again, similar to VSM and SMED, the majority of the experts did not know if there is a link between LIC and "struck by object" risks (57\%), "body reaction" risks (57\%) and the daily advance rate (43\%). This could mean that an assessment of the outcomes of implementing SMED on OHS and productivity indicators in the mining environment requires more study.

By combining all the statistical results related to each variable in this study, Figures 2-4 were produced. These figures present the experts' overall opinions about the possible connection and the predicted impacts of implementing a set of lean tools on "struck by object" risks (Figure 2), "body reaction" risks (Figure 3 ) and the daily advance rate in the Canadian underground gold-mining sector (Figure 4).

The experts' opinions about the current level of OHS in Canadian underground gold mining sector were recorded as well. Most of them believed that at 
the moment, the level of OHS in mining is satisfactory. They commented that from their point of view, OHS has been rapidly improving in the Canadian mining industry. It is worth mentioning that according to the mining association of Canada, the rate of worker accidents and injuries in the mining field has been decreasing in Canada over the past few years (Marshal, 2016). The experts' opinions about the existence of a health-related issue in connection to lean implementation are divided into two groups. One group of $43 \%$ of the experts commented that there could be psychological health concerns arising from increased stress among workers linked to the changes imposed by lean implementation. According to them, productivity and health do not always go together. On the

\section{OHS INDICATOR: STRUCK BY AN OBJECT}
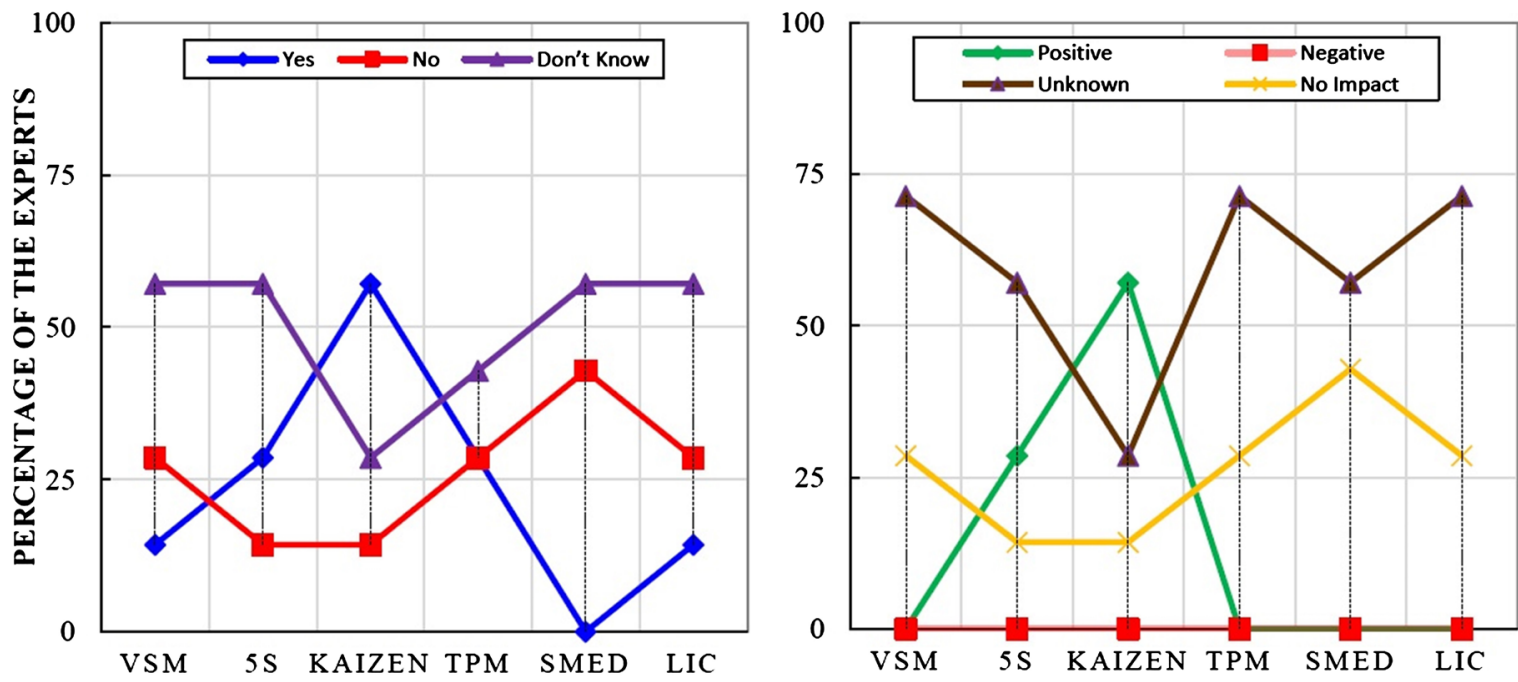

Figure 2. Experts' opinions about the possible connections (left) and the predicted impacts (right) of implementing a set of lean tools on "struck by an object" among workers in the Canadian underground gold-mining sector.

\section{OHS INDICATOR: BODY REACTION}
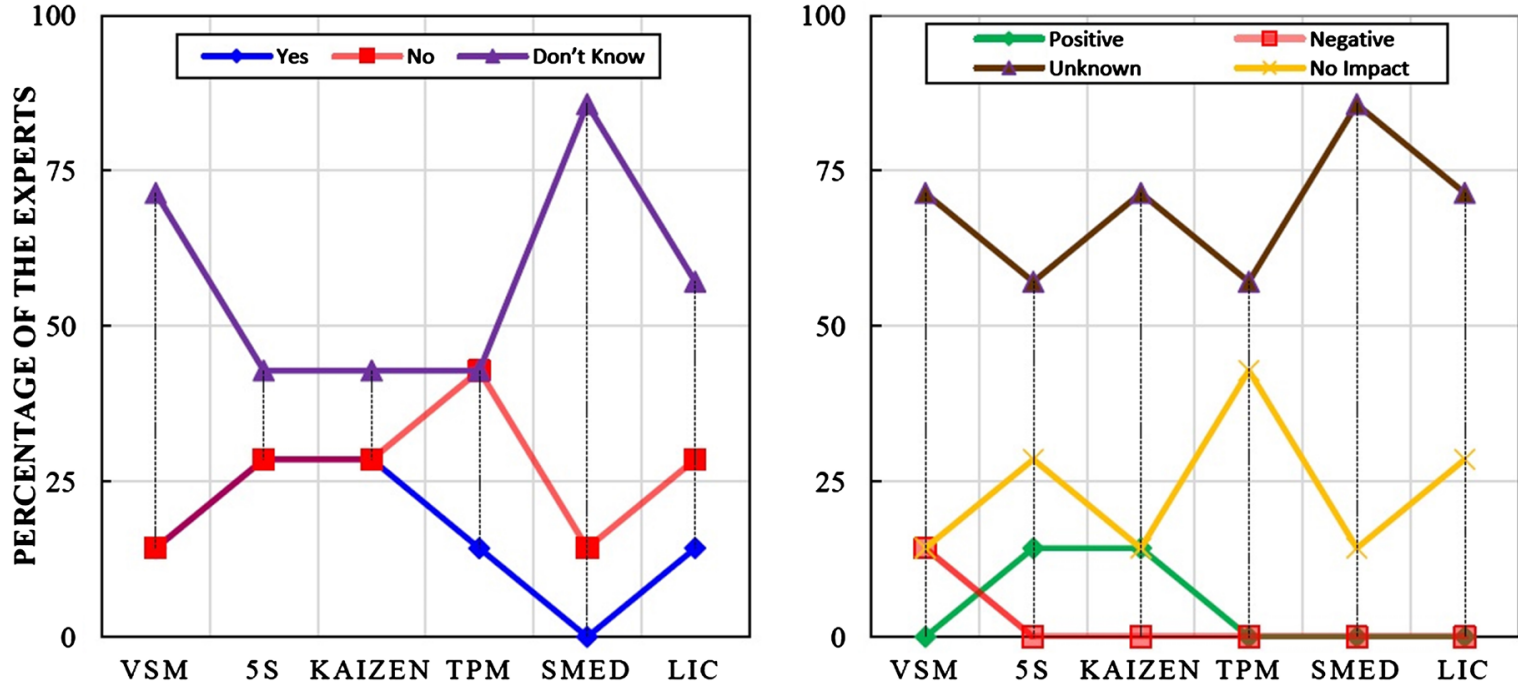

Figure 3. Experts' opinions about the possible connections (left) and the predicted impacts (right) of implementing a set of lean tools on "body reaction" among workers in the Canadian underground gold-mining sector. 
ECONOMIC INDICATOR: DAILY ADVANCE RATE
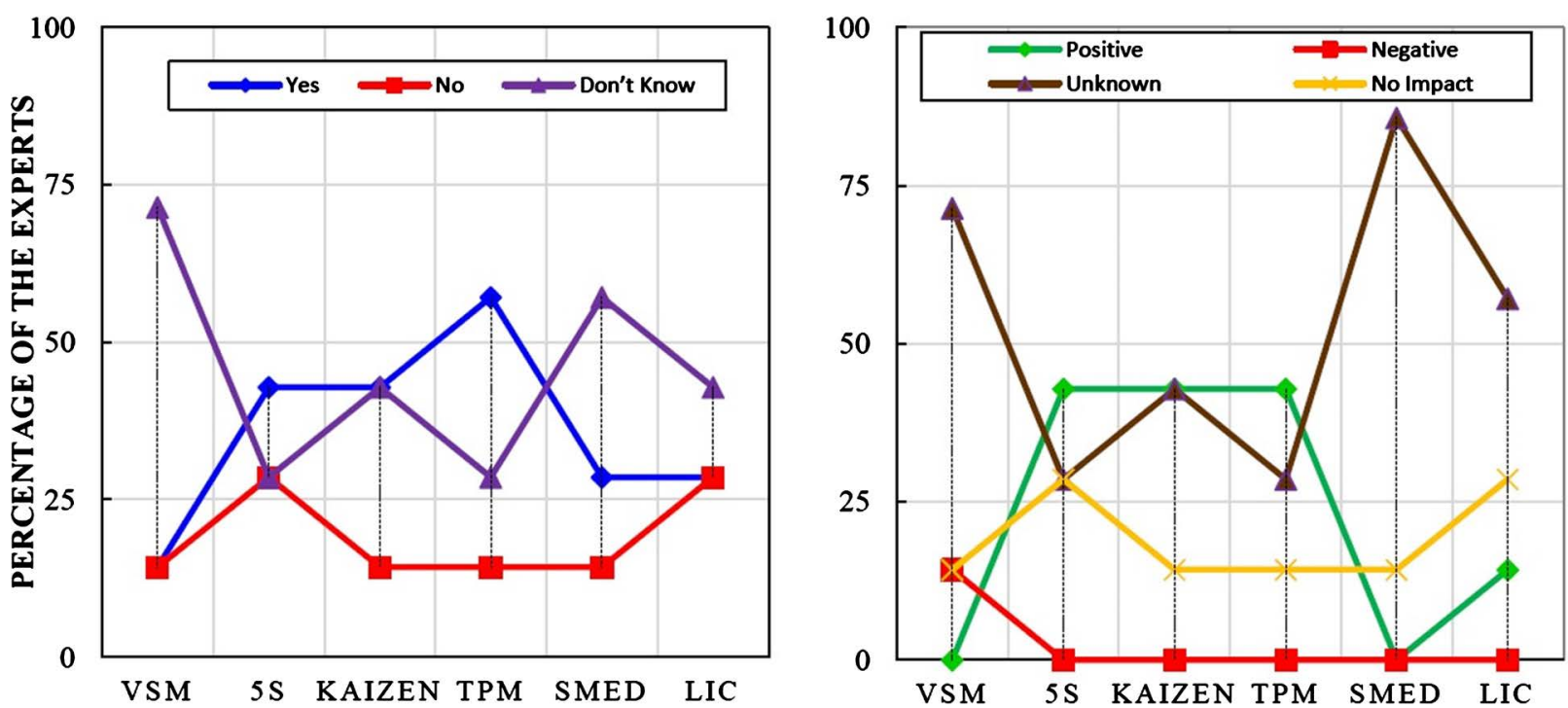

Figure 4. Experts' opinions about the possible connections (left) and the predicted impacts (right) of implementing a set of lean tools on "daily advance rate" in the Canadian underground gold-mining sector.

other hand, the other group (also 43\%) did not see the possibility of any health-related problems arising from implementing lean. By combining all the answers from the experts regarding the possible connection between implementing the set of lean tools and the two OHS indicators, it can be seen that around $54 \%$ of the experts' answers were that they did not know it there is a link between the implementation of lean and these two OHS indicators in mining (Figure 5(a)).

From an economic standpoint, all of the experts agreed that the current economic situation of Canadian underground gold mines is positive and also, that it is improving. Based on the literature, Canada is one of the biggest worldwide producers of minerals (and a major producer of key materials such as gold ores) (Brendan, 2016; Rupert \& Columbia, 2013) [45] [46]. On the other hand, the experts' opinions on a relationship between the economic indicator and lean implementation are again divided into two groups. The first group, $43 \%$ of the experts, believed that lean could be costly to implement in the beginning. Costs associated with implementation such as training and supervision are a few of the examples given by these experts. On the other hand, the other group of experts (43\%) did not see any economic-related problem connected to lean implementation. By combining all the answers from the experts regarding the relationship between implementing the selected set of lean tools and the economic indicator, it can be seen that about $45 \%$ of the experts' answers were that they did not know whether there is a connection between implementing lean and the economic indicator for mining (Figure 5(b)). An overview of the obtained results of this research is presented in Figure 6. This figure shows the final results of this study and generates a preliminary road-map to help implement lean mining and address the objective of this research. 


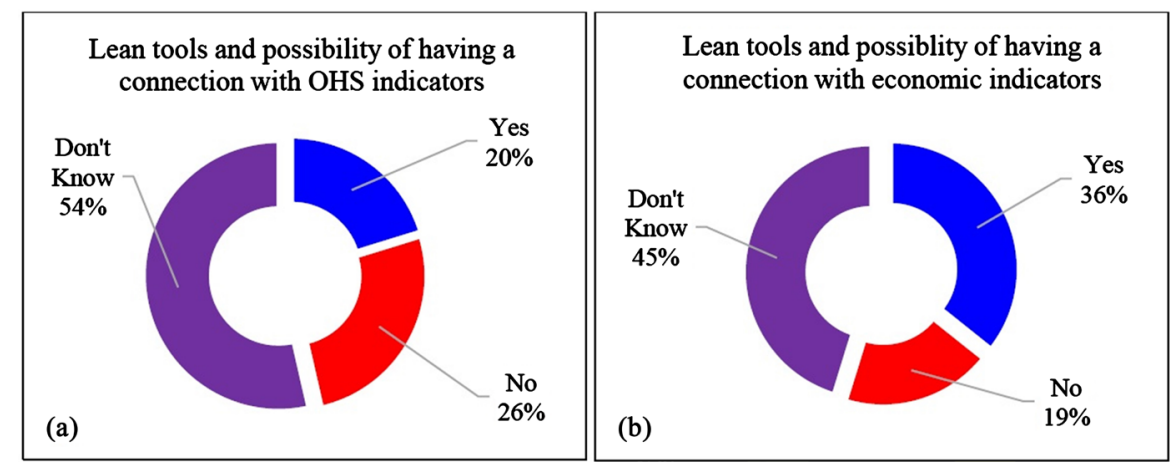

Figure 5. Experts' overall opinions regarding the existence of a possible connection between the set of lean tools, the two OHS indicators and the economic indicator in underground gold-mining environment (respectively (a), (b)).

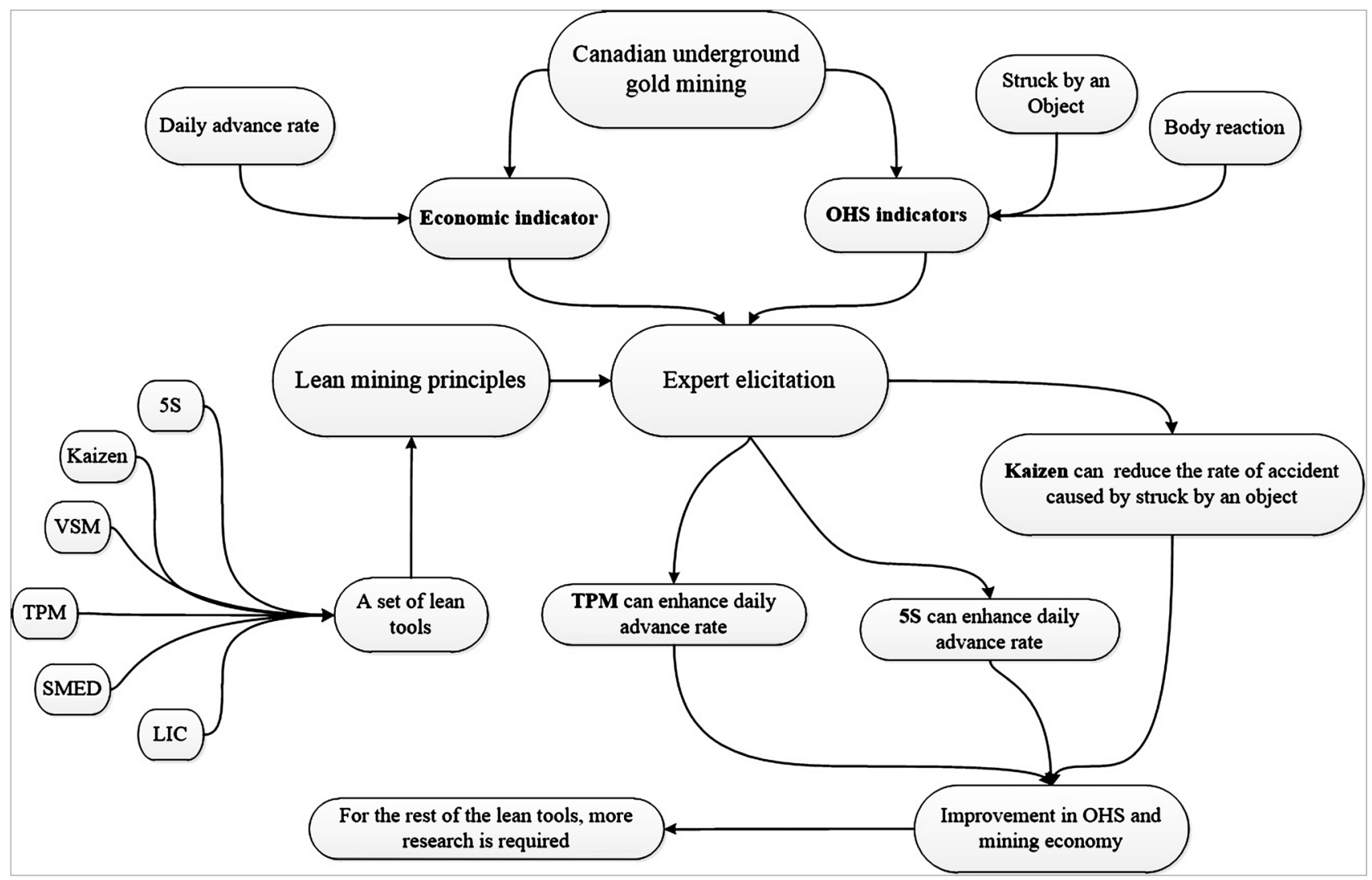

Figure 6. A preliminary road-map (created via mind-mapping) to implement lean mining, based on the findings of this study.

\section{Discussion}

\subsection{Limitations and Biases}

Initially, a total of 10 experts were recruited. 7 experts completed the questionnaire. The scientific community in lean mining in Canada is limited. The results of this research are limited to gold mining. Moreover, having such a small sample size prevents a generalization of the final results of this expert-elicitation study (Yin, 2013) [47]. On the other hand, for a study with little or no earlier background information, the qualitative expert-elicitation method provides the 
opportunity to gain some background information about the new topic (Baxter et al., 2008) [48]. Holding a semi-directed interview with Canadian experts can give more flexibility over the other types of interviews, for instance, asking more general and open-ended questions and generating comparable qualitative information (Bernard, 2011) [45]. This method is especially useful when not much experience about the studied subject has been documented a condition that applies to this study as well.

One of the possible biases of this research could be due to each expert's mindset about lean. Each expert might have their own perspective about lean, which could differ from that of the other experts. As mentioned in the results section, the majority of the experts described lean as an effective way to minimize loss of time, reduce costs and optimize production. This indicates that most of them see lean as a waste management tool to improve efficiency. This is in accordance with what was established as the definition of lean in this paper (Shah \& Ward, 2007) [24]. Another bias of this study is that almost none of the experts had any previous formal lean-related training. Some experts obtained their information about lean through readings and waste-elimination practices used by their mining companies, which could be considered as a form of training. However, this could have an impact on the presented results.

\subsection{Literature Comparison}

By comparing the findings of this study (Table 2) with the literature (Table 1) it can be noticed that these findings are consistent with what has been found by the above-mentioned authors using different research protocols. In the literature, $5 \mathrm{~S}$ and TPM were reported to be effective tools for production enhancement in coal, aluminum and copper mining (Chlebus et al., 2015; Liu, 2013; Dunstan et al., 2006) [16] [17] [21]. The same results for these tools were obtained in this study for underground gold mining. As for Kaizen, a possible improvement in miners' safety and health conditions was reported by Vaněk et al. (2015) [20] in coal mining. Decreasing the rate of the risk of being struck by an object after implementing Kaizen was one of this research's findings.

\subsection{Future Studies}

This study was an attempt to make an initial foray for further studies by creating a preliminary road-map to help implement lean in the mining sector regarding workers' health and safety. Future studies can focus on more field work observations and case studies to investigate lean mining more in depth. Knowing that results of this study were obtained for the underground gold-mining sector, other mining sectors should be involved in future studies as well, to create a more comprehensive and conclusive road-map regarding the connection between lean mining, OHS and productivity in Canadian mines.

One of the main objectives of this study was to investigate the connection between implementing lean and OHS and productivity in the mining environment. 
The final results showed that some lean tools can be effective in enhancing OHS and mining productivity. However, the impact of lean mining as a whole (implementing a set of lean tools) on OHS and productivity is still unknown (Fig. 5). The findings of this study are still inconclusive regarding this matter. This highlights the fact that lean in mining is still emerging in Canada and more research is required to reach more tangible conclusions.

\section{Conclusion}

Unlike the manufacturing sector, there are little information and studies about the outcome of lean integration in the other sectors. Moreover, implementing lean into Canadian mining sector is still emerging. To the best of our knowledge, very little information in the literature exists about the impact of lean implementation on mining productivity and OHS. The published information is even rarer regarding the Canadian mining sector. By conducting an expert-elicitation study with 7 Canadian experts, a preliminary road-map was created to show the possible links between lean mining and productivity and workers' safety in Canadian underground gold mining. This map can help to provide more in-depth knowledge about which lean tools would be better to start with for future case studies, to investigate more about the impacts of lean mining on OHS and productivity. Results from both the literature and this study show that tools such as $5 \mathrm{~S}$, TPM and Kaizen may potentially have positive impacts on mining productivity and OHS. This paper showed that using $5 \mathrm{~S}$ and TPM can increase the daily advance rate and Kaizen can be useful in reducing the rate of "struck by an object" risks among workers in underground gold mines in Canada. Although this study did not reach a conclusion about the outcome of implementing lean (as a set of tools) on OHS and productivity, it does, however, pave the way for further research about Canadian lean mining.

\section{Acknowledgements}

The authors of this paper would like to thank École de technologie supérieure for providing infrastructures, the Natural Sciences and Engineering Research Council (NSERC) for funding and all the experts who volunteered to participate in this research.

\section{Conflicts of Interest}

The authors declare no conflicts of interest regarding the publication of this paper.

\section{References}

[1] Malik, O.T. (1988) Toyota Production System: Beyond Large-Scale Production. CRC Press, Boca Raton.

[2] Shingo, S. and Dillon, A.P. (1989) A Study of the Toyota Production System: From an Industrial Engineering Viewpoint. CRC Press, Boca Raton.

[3] Womack, J.P., Jones, D.T. and Roos, D. (1990) Machine That Changed the World. 
Simon and Schuster, New York.

[4] Flynn, J.R. and Vlok, P.J. (2015) Lean Approaches in Asset Management within the Mining Industry. Proceedings of 2014 World Congress on Engineering Asset Management, Cham, 28-31 October 2014, 101-118.

https://doi.org/10.1007/978-3-319-15536-4_9

[5] Bhamu, J. and Sangwan, K. (2014) Lean Manufacturing: Literature Review and Research Issues. International Journal of Operations \& Production Management, 34, 876-940. https://doi.org/10.1108/IJOPM-08-2012-0315

[6] Sternberg, H., Stefansson, G., Westernberg, E., Boije af Gennäs, R., Allenström, E. and Linger Nauska, M. (2012) Applying a Lean Approach to Identify Waste in Motor Carrier Operations. International Journal of Productivity and Performance Management, 62, 47-65. https://doi.org/10.1108/17410401311285291

[7] Hodge, G.L., Goforth Ross, K., Joines, J.A. and Thoney, K. (2011) Adapting Lean Manufacturing Principles to the Textile Industry. Production Planning \& Control, 22, 237-247. https://doi.org/10.1080/09537287.2010.498577

[8] Lööw, J. (2018) An Investigation into Lean Production Practice in Mining. International Journal of Lean Six Sigma, 10, 123-142.

https://doi.org/10.1108/IJLSS-07-2017-0085

[9] Hasle, P. (2014) Lean Production: An Evaluation of the Possibilities for an Employee Supportive Lean Practice. Human Factors and Ergonomics in Manufacturing \& Service Industries, 24, 40-53. https://doi.org/10.1002/hfm.20350

[10] Sanchez, A.M. and Perez, M.P. (2004) The Use of Lean Indicators for Operations Management in Services. International Journal of Services Technology and Management, 5, 465-478. https://doi.org/10.1504/IJSTM.2004.006278

[11] Hattingh, T. and Keys, O. (2010) How Applicable Is Industrial Engineering in Mining. Proceedings of the 4th International Platinum Conference, Sun City, 11-14 October 2010, 205-210.

[12] Khaba, S. and Bhar, C. (2018) Lean Awareness and Potential for Lean Implementation in the Indian Coal Mining Industry: An Empirical Study. International Journal of Quality \& Reliability Management, 35, 1215-1231. https://doi.org/10.1108/IJQRM-02-2017-0024

[13] Nadeau, S., Morency, F. and Nsangou, J.R. (2015) The Contextualization of Lean Manufacturing in the Mining Sector: Forseeable Challenges to Occupational Health and Safety. Proceedings 19th Triennial Congress of the IEA: International Ergonomics Association, Melbourne, 9-14 August 2015, 1-5.

[14] Castillo, G., Alarcón, L.F. and González, V.A. (2014) Implementing Lean Production in Copper Mining Development Projects: Case Study. Journal of Construction Engineering and Management, 141, 1-10. https://doi.org/10.1061/(ASCE)CO.1943-7862.0000917

[15] Ade, M. and Deshpande, V.S. (2012) Lean Manufacturing and Productivity Improvement in Coal Mining Industry. International Journal of Engineering Research and Development, 10, 35-43.

[16] Dunstan, K., Lavin, B. and Sanford, R. (2006) The Application of Lean Manufacturing in a Mining Environment. Proceedings of the International Mine Management Conference: Australasian Institute of Mining and Metallurgy, Melbourne, 16-18 October 2006, 16-18.

[17] Liu, Z.X. (2013) Study on Coal Lean Mining Theory and Practice. Advanced Materials Research, 605, 538-541.

https://doi.org/10.4028/www.scientific.net/AMR.605-607.538 
[18] Flamarion Klippel, A., Petter, C.O., Antunes, J.R.V. and Antonio, J. (2008) Lean Management Implementation in Mining Industries. Dyna, 75, 81-89.

[19] Maunzagona, S.A. and Telukdarie, A. (2017) The Impact of Lean on the Mining Industry: A Simulation Evaluation Approach. INCOSE International Symposium, 27, 965-981. https://doi.org/10.1002/j.2334-5837.2017.00406.x

[20] Vaněk, M., Mikolá, M. and Pomothy, L. (2015) Continuous Improvement Management for Mining Companies. Journal of the Southern African Institute of Mining and Metallurgy, 115, 119-124. https://doi.org/10.17159/2411-9717/2015/v115n2a5

[21] Chlebus, E., Helman, J., Olejarczyk, M. and Rosienkiewicz, M. (2015) A New Approach on Implementing TPM in a Mine: A Case Study. Archives of Civil and Mechanical Engineering, 15, 873-884. https://doi.org/10.1016/j.acme.2015.07.002

[22] Hines, P., Taylor, D. and Walsh, A. (2018) The Lean Journey: Have We Got It Wrong? Total Quality Management \& Business Excellence, 29, 1-18. https://doi.org/10.1080/14783363.2018.1429258

[23] Stone, K.B. (2012) Four Decades of Lean: A Systematic Literature Review. International Journal of Lean Six Sigma, 3, 112-132. https://doi.org/10.1108/20401461211243702

[24] Shah, R. and Ward, P.T. (2007) Defining and Developing Measures of Lean Production. Journal of Operations Management, 25, 785-805.

https://doi.org/10.1016/j.jom.2007.01.019

[25] Ståhl, A.-C.F., Gustavsson, M., Karlsson, N., Johansson, G. and Ekberg, K. (2015) Lean Production Tools and Decision Latitude Enable Conditions for Innovative Learning in Organizations: A Multilevel Analysis. Applied Ergonomics, 47, 285-291. https://doi.org/10.1016/j.apergo.2014.10.013

[26] Mazzocato, P., Savage, C., Brommels, M., Aronsson, H. and Thor, J. (2010) Lean Thinking in Healthcare: A Realist Review of the Literature. Quality and Safety in Health Care, 19, 376-382. https://doi.org/10.1136/qshc.2009.037986

[27] Repenning, N.P. and Sterman, J.D. (2001) Nobody Ever Gets Credit for Fixing Problems That Never Happened: Creating and Sustaining Process Improvement. California Management Review, 43, 64-88. https://doi.org/10.2307/41166101

[28] Ferreira, T., Baptista, A., Azevedo, S. and Charrua-Santos, F. (2015) Tool Development for Support Lean Manufacturing Implementation in Intermittent Production Environment. Proceedings of the World Congress on Engineering 2015: WCE, London, 1-3 July 2015, 10-16.

[29] Dal Forno, A.J., Pereira, F.A., Forcellini, F.A. and Kipper, L.M. (2014) Value Stream Mapping: A Study about the Problems and Challenges Found in the Literature from the Past 15 Years about Application of Lean Tools. The International Journal of Advanced Manufacturing Technology, 72, 779-790.

https://doi.org/10.1007/s00170-014-5712-Z

[30] Adler, P.S. (1999) Hybridization: Human Resource Management at Two Toyota Transplants. Remade in America: Transplanting and Transforming Japanese Management, Oxford.

[31] De Treville, S. and Antonakis, J. (2006) Could Lean Production Job Design Be Intrinsically Motivating? Contextual, Configurational, and Levels-of-Analysis Issues. Journal of Operations Management, 24, 99-123. https://doi.org/10.1016/j.jom.2005.04.001

[32] Brenner, M.D., Fairris, D. and Ruser, J. (2004) "Flexible" Work Practices and Occupational Safety and Health: Exploring the Relationship between Cumulative 
Trauma Disorders and Workplace Transformation. Industrial Relations. A Journal of Economy and Society, 43, 242-266. https://doi.org/10.1111/j.0019-8676.2004.00325.x

[33] Brännmark, M. and Håkansson, M. (2012) Lean Production and Work-Related Musculoskeletal Disorders: Overviews of International and Swedish Studies. Work, 41, 2321-2328.

[34] Westgaard, R.H. and Winkel, J. (2011) Occupational Musculoskeletal and Mental Health: Significance of Rationalization and Opportunities to Create Sustainable Production Systems-A Systematic Review. Applied Ergonomics, 42, 261-296. https://doi.org/10.1016/j.apergo.2010.07.002

[35] Creswell, J.W. (2013) Research Design: Qualitative, Quantitative, and Mixed Methods Approaches. Sage Publications, Thousand Oaks.

[36] Fortin, M.F. (2010) Foundations and Stages of the Research Process: Quantitative and Qualitative Methods. 2nd Edition, Chenelière Éducation, Montréal.

[37] O’Hagan, A., Buck, C.E., Daneshkhah, A., Eiser, J.R., Garthwaite, P.H., Jenkinson, D.J. and Rakow, T. (2006) Uncertain Judgements: Eliciting Experts' Probabilities. John Wiley \& Sons, Hoboken. https://doi.org/10.1002/0470033312

[38] Nemati, A., Nadeau, S., Ateme-Nguema, B. and Belmont, J. (2019) Identifying Lean Tools to Improve Mining Productivity and OHS Conditions. 13th International Conference on Industrial Engineering, Montréal, 25-28 June 2019, 89-98.

[39] MERN du Québec, G. (2012) Report on Mining Activities in Québec 2011. Direction Générale de Géologie Québec, Gouvernement du Québec, Québec.

[40] Committee on Standards, Equity, Health and Safety at Work (CNESST) (2011) Main Injury Risk by Sector of Activity. In CSST: Prevention.

[41] Pareja, L.D. (2000) Deep Underground Hard-Rock Mining: Issues, Strategies, and Alternatives. PhD Thesis, Queen's University, Kingston.

[42] Lehto, M.R. and Buck, J.R. (2008) An Introduction to Human Factors and Ergonomics for Engineers. Lawrence Erlbaum, Mahwah.

[43] Nielsen, J. (1993) Usability Engineering. AP Professional, New York. https://doi.org/10.1016/B978-0-08-052029-2.50007-3

[44] Berg, B.L. (2001) Qualitative Research Methods for the Social Sciences. Fourth Edition, Allyn \& Bacon, Boston.

[45] Bernard, H.R. (2011) Research Methods in Anthropology: Qualitative and Quantitative Approaches. Rowman Altamira, Lanham, Maryland.

[46] Rupert, P. and Columbia, B. (2013) Asian Consortium Takes 15\% Stake in ArcelorMittal Mines Canada. Engineering and Mining Journal, 214, 8-10.

[47] Yin, R.K. (2013) Case Study Research: Design and Methods. Sage Publications, Thousand Oaks.

[48] Baxter, P. and Jack, S. (2008) Qualitative Case Study Methodology: Study Design and Implementation for Novice Researchers. The Qualitative Report, 13, 544-559. 